Editorial

\title{
Acting on Media: Influencing, Shaping and (Re)Configuring the Fabric of Everyday Life
}

\author{
Sigrid Kannengießer* and Sebastian Kubitschko \\ Centre for Media, Communication and Information Research (ZeMKI), University of Bremen, 28359 Bremen, Germany; \\ E-Mails: sigrid.kannengiesser@uni-bremen.de (S.K.), sebastian.kubitschko@uni-bremen.de (S.K.) \\ * Corresponding author
}

Submitted: 18 September 2017 | Published: 22 September 2017

\begin{abstract}
Computerization, digitalization and datafication are by far no neutral or self-dependent occurrences. They are, to a large degree, co-determined by heterogeneous actors who reflect about, construct, configure, manipulate or even control media. The contributors to this issue put the spotlight on these actors and investigate how they influence, shape and (re)configure broader social constellations. Instead of exploring what people do with media, the articles focus on the many ways individuals, civil society initiatives, corporations and social movements act on media. The notion of acting on media denotes the efforts of a wide range of actors to take an active part in the molding of media organizations, infrastructures and technologies that are part of the fabric of everyday life. Therefore, by conceptualizing acting on media as a form of political action, the issue aims to contribute to ongoing discussions on the media practice paradigm.
\end{abstract}

\section{Keywords}

acting on media; civil society organizations; media appropriation; media corporations; media practice; social movements

Issue

This editorial is part of the issue "Acting on Media: Influencing, Shaping and (Re)Configuring the Fabric of Everyday Life", edited by Sigrid Kannengießer and Sebastian Kubitschko (University of Bremen, Germany).

(C) 2017 by the authors; licensee Cogitatio (Lisbon, Portugal). This article is licensed under a Creative Commons Attribution 4.0 International License (CC BY).

Media-understood as organizations, infrastructures and technologies-are inseparably connected with and embedded in the way social, cultural, economic and political life is experienced and practiced today. To separate "media" on the one hand and "society" on the other hand has turned into an impossible endeavor today. Looking at current processes of computerization, digitalization and datafication one has to acknowledge that these are by far no neutral or self-dependent occurrences. They are, to a large degree, co-determined by heterogeneous actors-many of them holding competing worldviews and representing conflicting interestswho reflect about, construct, configure, manipulate or even control media. Hence, (digital) transformations are not merely "technical", but deeply politically charged processes embedded in broader social constellations.

"What, quite simply, are people doing in relation to media across a whole range of situations and contexts?"
(Couldry, 2004, p. 119). Taking Nick Couldry's seemingly banal query as a point of departure this issue further elaborates the notion of "doing something in relation to media". Hence, instead of exploring what people do with media, the following articles turn the spotlight to the many ways civil society initiatives, corporations or social movements act on media. Acting on media denotes the efforts of a wide range of actors to take an active part in the molding of media organizations, infrastructures and technologies that are part of the fabric of everyday life. It is understood that those who act on media materialize in all kinds of formations-individual and collective; scattered and organized; civic, corporate and governmental; as well as hybrids thereof. Consequently, acting on media entails insider and outsider tactics, contentious and institutionalized undertakings, direct and indirect action, and many mixed forms that exist amongst these occurrences. 
Using the notion of acting on media, we aim to contribute a valuable portion to the practice paradigm. More concretely, we argue that the term media practice is best understood in a broad sense, which includes a sorrow analysis of how and why people act on media as organizations, infrastructures and technologies (Kannengießer, 2016, in press; Kubitschko, 2017). In consideration of revealing empirical and analytical insights on the inseparable relation between media and society by scholars across various disciplines it is understood that those who act on media also influence, shape and (re)configure the fabric of everyday life. Acting on media, like other forms of political action, is best characterized as a set of practices that are embedded in and at the same time produce constellations of power (related, amongst others, to gender, class, age and education). Here it is important to note that taking an active part in the molding of media is neither exclusively linked to current processes of digitalization and datafication nor can it only be found in (post)industrialized societies. In fact, historical explorations as well as transcultural perspectives provide much-needed contextualizations of the ways media organizations, infrastructures and technologies are (re)configured across the globe.

The contributors to this issue are united by their aim to address the following key questions: Who are the (established and emerging) actors that thematize, influence and shape contemporary media? What are the concrete strategies and practices of actors who act on media? Which discourses do they counter or fuel? What political implications do their actions have and which political aims do these actors follow? Accordingly, by bringing together both empirical research and theoretical contributions, this thematic issue tackles a number of critical aspects that remain largely unresolved so far in media and communication studies: Who has the capacity, resources, expertise and interest to act on the media that are part of the fabric of everyday life? How do established and emerging forms of taking an active part in the molding of media organizations, infrastructures and technologies merge, collide or drift apart? Finding convincing answers to these (and similar) questions becomes ever more imperative for adequate recognitions of contemporary power structures and for gaining a better understanding of concrete societal transformations.

In their article "Variants of Interplay as Drivers of Media Change" Tilo Grenz and Paul Eisewicht (2017) take three qualitative case studies (Wii hacking, Circuit Bending and online poker tools) as a basis for their argumentation that we should "view acting on media as a negotiation between differently motivated and dissimilarly powerful actors and groups" (p. 7). To explicate this approach the authors investigate the relations between users, user communities and producers of digital media by focusing on people's creative practices oriented around media objects. Grenz and Eisewicht suggest that acting on media is not necessarily driven by ideology, political motivations or creative competencies, but by a "thrill of such action as unfolded within more or less anonymous spaces that drives people to open up closed systems, to interfere with official rule sets, to circumvent structures, and to modify media technology" (p. 11).

In "Fan (Fiction) Acting on Media and the Politics of Appropriation" Wolfgang Reißmann, Moritz Stock, Svenja Kaiser, Vanessa Isenberg and Jörg-Uwe Nieland (2017) take the political implications of media appropriation into account when analyzing fanfiction as practices of acting on media in the German context. The authors define fanfiction as the "creative appropriation and transformation of existing media texts by fans" (p. 19) and argue that fanfiction can be defined as acting on media in two ways. First, fans create infrastructures like communities and publics to circulate and share the content they produce; and second, fans act on the political and juridical conditions which frame these publication processes. Reißmann et al. (2017) argue that although fans are located in a rather weak position from a juridical point of view-they neither own the material they modify nor do they have a grand legal framework to navigate-fans appropriate exiting media texts and thereby take up power positions. Although fanfiction can take place individually it is often a collective endeavor based on discussing, commenting on or modifying existing media texts together.

Taking collective action into account from a different point of view, Sarah Myers West (2017) examines in "Raging Against the Machine: Network Gatekeeping and Collective Action on Social Media Platforms" how social media users (try to) redistribute power and put pressure on media companies and their policies by producing campaigns. By examining different campaigns on Facebook, Myers West manages to demonstrate a fascinating interrelationship: on the one hand she analyzes the way a corporation acts on media on the basis of its community guidelines and content moderations. On the other hand, the author shows how Facebook users act on media by trying to change these policies and the media content which can be produced within the context of the platform. Thereby, Myers West unfolds the relation between media companies like Facebook and its users as a multifaceted phenomenon whereby acting on media manifests itself as negotiating media content as well as media regulations.

Interviewing media managers, Johanna Möller and Bjørn von Rimscha (2017) analyze in "(De)Centralization of the Global Informational Ecosystem" how contentoriented media companies act on media in relation to data, infrastructures and distribution. The authors provide a three-dimensional framework of (de)centralization, which shows how content-based media companies contribute to and push centralization processes pursued by Facebook, Google, and other major players in the field who serve as role models for intra-organizational technological adaption as well as critical channels for content distribution. Ultimately, Möller and von Rimscha argue that discussing (de)centralization from a techno- 
economic perspective is a worthwhile endeavor because it allows to illustrate how content-based media companies deal with infrastructural disadvantages and develop distinct strategic models to accomplish their business goals.

Reconstructing the perspective of members of the Occuppy Wall Street movement, Michael Daubs and Jeffrey Wimmer (2017) show in "Forgetting History: Mediated Reflections on Occupy Wall Street" how activists reflect on the role of media for "their" movement regarding the way they historize current political activism. Using this empirical example, the authors argue that a "non-mediacentric" approach to analyze social movements' media appropriation underlines the relevance of non-digital media and communication processes for social movements.

While Daubs and Wimmer show how activists reflect on media and the way they are and could be used, Hilde Stephansen (2017) argues in "Media Activism as Movement? Collective Identity Formation in the World Forum of Free Media" that media themselves are increasingly becoming subjects of activism. Analyzing the case of the World Forum of Free Media (FMML), a forum for media activists which is part of the World Social Forum, she explores the collective identity formation within FMML and asks whether it can be perceived as a new movement focusing on media and technology issues. Stephansen's analysis shows how social movements act on media as the very object of their activism. At the same time, however, the author clarifies that the term "free media" as the object and goal of this kind of activism experiences a plural definition within the movement-depending on the diversity of actors who are involved in it and the contexts within which the movement is active. Acting on media therefore strongly depends on the type of actors and their background as well as on the national and cultural contexts these actors are embedded in.

Analyzing how individuals, collectives, movements or corporations influence, shape and (re)configure the fabric of everyday life by acting on media there are several components that we should take serious: the type of actors who are involved (Who is acting?), the purpose of the actors (Why do they act and what do they act for?), the way the actors take action (What do they do?), the wider scenario within which action takes place (What is the context?), and, ideally, the outcomes of their actions (What are the consequences?). Asking these question, we always have to bear in mind existing and emerging power structures that are inscribed in the processes of acting on media: Who is able to act on media and who is not? What kind of practices remain invisible? Whose actions do not only influence media organizations, infrastructures and technologies, but affect larger social constellations?

\section{Acknowledgements}

The editors would like to thank all contributors to this issue as well as all participants (and the co-organizer An- dreas Hepp) of the "Acting on Media" workshop, sponsored by the Media Sociology Section of the German Communication Association (DGPUK) and the Creative Unit "Communicative Figurations" at the Centre for Media, Communication and Information Research (ZeMKI), University of Bremen, that was funded within the frame of the Excellence Initiative by the German Federal and State Governments. Sebastian Kubitschko's contribution took place in the context of this Creative Unit. Sigrid Kannengießer's postdoctoral research on "Consumer-Critical Media Practices" is financed by the central research funding unit at the University of Bremen.

\section{Conflict of Interests}

The authors declare no conflict of interests.

\section{References}

Couldry, N. (2004). Theorising media as practice. Social Semiotics, 14(2), 115-132.

Daubs, M. S., \& Wimmer, J. (2017). Forgetting history: Mediated reflections on Occupy Wall Street. Media and Communication, 5(3), 49-58.

Grenz, T., \& Eisewicht, P. (2017). Variants of interplay as drivers of media change. Media and Communication, 5(3), 5-14.

Kannengießer, S. (2016). Conceptualizing consumptioncritical media practices as political participation. In L. Kramp, N. Carpentier, A. Hepp, R. Kilborn, R. Kunelius, H. Nieminen, ... S. Tosoni (Eds.), Politics, civil society and participation (pp. 193-207). Tartu: Tartu University Press.

Kannengießer, S. (in press). Repair Cafés as communicative figurations: Consumer-critical media practices for cultural transformation. In A Hepp, U. Hasebrink, \& A. Breiter (Eds.), Communicative figurations. Rethinking mediatized transformations. Palgrave: London.

Kubitschko, S. (2017). Acting on media technologies and infrastructures: Expanding the media as practice approach. Media, Culture \& Society. doi:10.1177/ 0163443717706068

Möller, J., \& von Rimscha, M. B. (2017). (De)centralization of the global informational ecosystem. Media and Communication, 5(3), 37-48.

Reißmann, W., Stock, M., Kaiser, S., Isenberg, V., \& Nieland, J.-U. (2017). Fan (fiction) acting on media and the politics of appropriation. Media and Communication, 5(3), 15-27.

Stephansen, H. C. (2017). Media activism as movement? Collective identity formation in the World Forum of Free Media. Media and Communication, 5(3), 59-66.

West, S. M. (2017). Raging against the machine: Network gatekeeping and collective action on social media platforms. Media and Communication, 5(3), 28-36. 


\section{About the Authors}

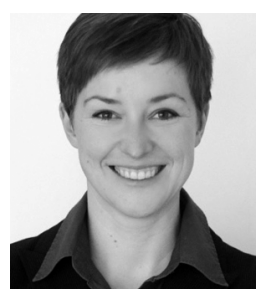

Sigrid Kannengießer is a post-doctoral researcher at the Centre for Media, Communication and Information Research, University of Bremen, Germany. Her research interests are in media sociology, environmental communication, transcultural and political communication, gender media studies. In her current research project she analyses consumer-critical media practices and thereby the interrelation between media appropriation and sustainability.

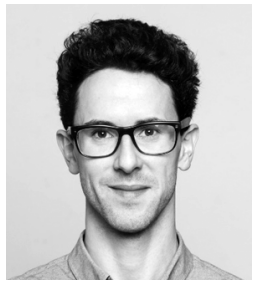

Sebastian Kubitschko is a post-doctoral researcher at the University of Bremen's Centre for Media, Communication and Information Research (ZeMKI), Germany. The main focus of his research is on the societal implications of media technologies and infrastructures, the political relevance of hacker organisations and, more recently, emerging power relations in the field of artificial intelligence (Al). Together with Anne Kaun he is the editor of Innovative Methods in Media and Communication Research (2016) published by Palgrave Macmillan. 